\title{
The BRITISH SCHOOL at ROME
}

Registered charity no. 314176

The British School at Rome is a centre of interdisciplinary research excellence in the Mediterranean supporting the full range of arts, humanities and social sciences. We create an environment for work of international standing and impact from Britain and the Commonwealth, and a bridge into the intellectual and cultural heart of Rome and Italy.

The BSR supports:

- residential awards for visual artists and architects

- residential awards for research in the archaeology, history, art history, society and culture of Italy and the Mediterranean

- exhibitions, especially in contemporary art and architecture

- a multidisciplinary programme of lectures and conferences

- internationally collaborative research projects, including archaeological fieldwork

- a specialist research library

- monograph publications of research and our highly-rated journal, Papers of the British School at Rome

- specialist taught courses.

For further information (including details of programmes, membership and publications) see: www.bsr.ac.uk 


\section{CONTENTS}

I MAUReEn CARroll, Mater Matuta, 'fertility cults' and the integration of women in religious life in Italy in the fourth to first centuries BC

47 ANDREW FOx, Trajanic trees: the Dacian forest on Trajan's column

7I PIER LUIGI TUCCI, Living on the Capitoline Hill: the domus of the Aracoeli and its sculptural and painted decoration

I45 ROBERT COUZIN, Where did all the pagans go? The non-Christian sarcophagi of fourth-century Rome

I77 HENDRIK DEY, Politics, patronage and the transmission of construction techniques in early medieval Rome, c. 650-750

207 TEODORO DE GIORGIO, Le storie della passione di Cristo della cappella «degli Illustrissimi» nel duomo di Napoli. Riflessioni sul triangolo Napoli, Siena e Avignone

245 LOEK LUITEN, 'Like a lily amongst the thorns': patterns of noble power and violence between Farnese and Orsini, 1378-1447

267 LOUIS CELLAURO, In quest of comfort: Carlo Lodoli, theorist of organic architecture and furniture designer

309 AMANDA CLARIDGE AND CHRISTOPHER SIWICKI, Notes from Rome, 2018-19

3 I 7 ARCHAEOLOGICAL FIELDWORK REPORTS

349 RESEARCH REPORTS 